UDK: $811.112 .2 ' 373 \cdot 7$

811.163.42'373.7

Pregledni članak

Primljen 30. IV. 2019.

Senka Marinčić - Magdalena Ramljak - Darija Glibić Filozofski fakultet Sveučilišta u Mostaru

senka.marincic@ff.sum.ba -magdalena.ramljak@ff.sum.ba-darija.glibic@ ff.sum.ba

\title{
FRAZEMI S BIBLIJSKIM OSOBNIM IMENIMA U NJEMAČKIM I HRVATSKIM RJEČNICIMA
}

\section{Sažetak}

U radu se analiziraju frazemi s biblijskim osobnim imenima kao sastavnicom u njemačkome kao jeziku polazniku i hrvatskome kao jeziku cilju, pri čemu se oslanjamo na tipologiju ekvivalencije u okviru kontrastivne frazeologije. Cilj je rada istražiti biblijsko podrijetlo frazema, obrazložiti njihovu pozadinsku sliku, motivaciju i značenje te ustvrditi stupanj njihove ekvivalencije. U prikupljanju građe rabili smo jednojezične i dvojezične frazeološke rječnike i opće jednojezične i dvojezične rječnike. Sukladno očekivanjima najviše su zastupnjeni frazemi s biblijskim osobnim imenom kao sastavnicom, a koji pokazuju djelomičnu i potpunu podudarnost leksemske i morfosintaktičke strukture uz istovjetnost frazeološkoga značenja. Neočekivano veliku skupinu čine frazemi koje analizirana hrvatska građa ne bilježi, iako se u biblijskim tekstovima često nalaze doslovni prijevodi.

Ključne riječi: frazem; biblijsko osobno ime; ekvivalencija; njemački; hrvatski 


\section{Uvod}

Iako su primjeri poput Er ist ein ungläubiger Thomas. / On je nevjerni Toma. (ein ungläubiger Thomas / nevjerni Toma $\rightarrow$ Iv 20, 24-29) ili Er ist geduldig wie Hiob. / On je strpljiv kao Job. (geduldig wie Hiob / strpljiv $k a o$ Job $\rightarrow$ Job 1,21) motivirani biblijskim tekstovima, oni su dijelom svakodnevnoga govora i komunikacije i onih koji žive po njezinim načelima i onih koji imaju druga vjerovanja. U mnogim je europskim jezicima i književnosti, pa i kulturama, Biblija ostavila upečatljiv trag. Posebice je zanimljivo kako su sasvim "obične“ riječi iz svakodnevnoga govora biblijski motivirane (usp. der Apfel / jabuka, die Schlange / zmija, das Gelobte Land / obećana zemlja, das letzte Abendmahl / Posljednja večera, Judas / Juda, Nazareth / Nazaret, Adam und Eva / Adam i Eva, Ost und West / istok i zapad, Himmel und Erde / nebo i zemlja itd.). Današnji biblijski frazemi (usp. ein ungläubiger Thomas / nevjerni Toma), za razliku od biblijskih izreka (usp. Reichtum macht viel Freunde; aber der Arme wird von seinem Freunde verlassen. / Bogatstvo pribavlja mnoge prijatelje, a siromaha i njegov prijatelj ostavlja. $\rightarrow$ Izr 19,4) i biblijskih citata (usp. Die Wahrheit wird euch frei machen. / Istina će vas osloboditi. $\rightarrow I v 8,32$ ), imaju brojne varijacije jer su pripis(iv)ani nekomu drugom povijesnom događaju, tako da njihovo biblijsko podrijetlo često pada $\mathrm{u}$ drugi plan i teško ga je odmah prepoznati. Uz frazeme antičkoga prodrijetla i frazeme književne provenijencije frazemi biblijskoga podrijetla predmet su istraživanja internacionalne frazeologije (usp. Vidović Bolt 2011: 43-47).

\section{O frazemu}

„Frazemi kao ustaljeni sklopovi riječi sa stalnim značenjem i invarijantnom strukturom su leksikološki gledano vrlo složeni, jer se njihovo značenje ne može rekonstruirati iz značenja njihovih sastavnica“ (usp. Ivanetić - Karlavaris-Bremer 1994: 4). Povezujući se s drugim riječima, pojedine riječi stvaraju pritom sveze riječi koje se prema značenju dijele na slobodne i frazeološke. U slobodnim svezama svaka sastavnica zadržava svoje značenje, pa značenje cijele sveze predstavlja zbroj, odnosno 
kombinaciju tih pojednačnih značenja, dok u frazeološkim svezama odnosno frazemima dolazi do promjene, tj. gubitka značenja najmanje jedne od sastavnica, pa značenje cijele sveze ne proistječe iz značenja pojedinih sastavnica (usp. Turk 1994: 38). Frazemi se od fonetske riječi (usp. bez daljnjega; preko noći; milo mi je [...] (Menac 1978: 221), skupa riječi (usp. živ i zdrav; plava krv; pružiti otpor [...] (Kolenić 1998: 78)) i rečenice (usp. u tom grmu leži zec; kaži Jakovu, a on će svakomu; to je da čovjeku pamet stane [...] (Menac 1978: 221)) odvajaju idiomatičnošću, semantičko-sintaktičkom stabilnošću, leksikalizacijom i reproduktivnošću (usp. Fleischer 1997: 31-37).

\section{2. (Osobno) ime u frazeologiji}

U frazeologiji vlada mišljenje da frazemi s (osobnim) imenom kao sastavnicom tvore specifičnu frazemsku skupinu, imaju specifičan mikrosustav te da se etimološkom analizom pojedinoga antroponima može odrediti značenje frazema. Odabir (osobnoga) imena u frazeološkoj svezi nije slučajan. Ono u podsvijesti govornika izaziva asocijaciju koja je povezana sa denotatom, tj. nositelj je odlučujućega značenja u jednoj takvoj svezi. Dakako da se u obzir moraju uzeti i druge sastavnice frazeološke sveze jer su i one dio tih sveza riječi, čije se semantičko značenje može ostvariti samo kada se koriste kao cjelina (usp. Matešić 1997: 139). Dakle, ime u frazemu ne funkcionira kao ime, nego kao nositelj frazemskoga značenja, odnosno „imena prestaju biti imena jer su izgubila semantički nebrojiv oblik pojedinačnosti, a semantičkim pomakom te su riječi dobile semantički nebrojiv oblik cjelovitosti“ (usp. Peti 1999: 106). Izvan frazema ime i dalje ima funkciju imena. Iako ih je zahvaljujući prisutnosti onomastičke sastavnice lako prepoznati (usp. Ribarova 2001: 74-77), ne moraju se u istome obliku pojaviti u Bibliji jer su vrlo često motivirani cijelim događajem, pričom ili osobinom biblijskoga lika ${ }^{1}$.

S tim u svezi treba razlikovati izravne biblizme kao točne izvedenice poslovica, izreka, uzrečica, frazema i kolokacija tekstova iz Biblije u svojemu završnom obliku i neizravne biblizme kao jedinice nastale samostalnom kombinacijom biblijskih riječi, slika i sižea koji se ne nalaze u samome tekstu Biblije (v. više u Opašić 2013). 
(Osobno) ime koje se pojavljuje u frazeološkoj svezi može biti tipično samo za jedan jezik (usp. Martin iz Zagreba, Martin u Zagreb / dumm geboren und nichts dazugelernt (Matešić 1988: 279)), potjecati iz bajki i mitologije (usp. Ahilova peta / Achillesferse „empfindliche Stelle, schwacher Punkt"(ebd.: 136)), biti preuzeto iz onimije drugoga jezika (usp. Kolumbovo jaje / das Ei des Kolumbus „eine überraschend einfache Lösung“ (Duden 1992: 168)) ili, pak, biti biblijskoga podrijetla (usp. Judin poljubac / Judaskuss „Kuss eines Verräters, Freundlichkeit aus verräterischer Absicht (Wahrig 2001: 700)). Frazeme s (osobnim) imenom karakterizira „smisaona cjelovitost, reproduktivnost, semantička i stilistička markiranost i česta pripadnost književnom sloju“ (usp. Ribarova 2001: 71). Oni mogu simbolizirati određenu ljudsku osobinu, način ponašanja ili su, pak, simbolom nekoga događaja. Tako, primjerice, Metuzalem simbolizira starost, a Juda izdaju. ${ }^{2}$ Frazemi s biblijskim osobnim imenom predstavljaju zajedničko kulturno nasljeđe svih kršćanskih naroda u njihovim jezicima (usp. Ribarova 2001: 71-73).

\section{Korpus i istraživanje}

Frazeme s biblijskim osobnim imenom u njemačkome kao jeziku polazniku, a koji se analiziraju za potrebe ovoga priloga, ekscerpirali smo iz sljedećih jednojezičnih i dvojezičnih frazeoloških i jednojezičnih i dvojezičnih općih rječnika: Duden 11 (1992., 1993.), Hansen-Kokoruš Matešić - Pečur-Medinger - Znika (2005.), Kraus (1993.), Mikić - Gojmerac (2017.), Röhrich (1995.), Schäfer (1998.), Wahrig (2001.). Potvrdu za njihove (ne)ekvivalente u hrvatskome kao jeziku cilju potražili smo u sljedećim jednojezičnim i dvojezičnim frazeološkim i jednojezičnim i dvojezičnim općim rječnicima: Anić (2004.), Cvitković (2005.), Hrvatski enciklopedijski rječnik 1-12 (2002.), Klaić (1990.), Matešić (1982.), (1988.), Menac - Fink Arsovski - Venturin (2003.), Mikić - Gojmerac (2011.), Mrazović, Primorac (1981.) i Rječnik biblijske kulture (1999.). ${ }^{3}$ Pri

2 Iako osobno ime može postati i apelativ (usp. Juda = izdajnik), to nije predmet ovoga priloga (v. više o apelativima u Opašić 2014.).

3 Budući da je jezik polaznik u ovome prilogu njemački, izostala je analiza frazema s biblijskim osobnim imenom koji se javlja samo u hrvatskome (usp. držati se/stajati kao drvena 
tumačenju simbolike i podrijetla pojedinoga biblijskog osobnog imena konzultirana je, osim navedenih rječnika, i sama Biblija.

Cilj je rada istražiti biblijsko podrijetlo frazema, obrazložiti njegovu pozadinsku sliku ${ }^{4}$, motivaciju i značenje, čime se pokazuje da je biblijsko osobno ime kao sastavnica frazema siguran pokazatelj njegova podrijetla. Svakomu se frazemu međujezične sličnosti i razlike određuju prema stupnju ekvivalencije. Analiza se ekscerpiranih frazema ${ }^{5}$ oslanja na tri tipa ekvivalencije koju Csaba Földes (1996: 117-136) označuje kao potpunu, djelomičnu i nultu ekvivalenciju.

\subsection{Ekvivalencija}

\subsubsection{Potpuna ekvivalencija}

Kod ovoga tipa ekvivalencije frazemi u obama jezicima pokazuju jednako denotativno značenje, potpunu strukturnu i leksemsku podudarnost frazemskih sastavnica i podudarnost frazemske pozadinske slike, odnosno potpunu podudarnost na izražajnoj i sadržajnoj razini frazema (usp. za ilustraciju navode se sljedeći primjeri iz našega korpusa: geduldig wie Hiob = strpljiv kao Job; ein armer Lazarus = ubogi Lazar [...]).

\subsubsection{Djelomična ekvivalencija}

Kod ovoga tipa ekvivalencije kontrastirani frazemi zadržavaju isto ili slično denotativno značenje, ali se međusobne razlike mogu manifestirati na više razina i to u okviru morfosintaktičke, leksemske i tvorbene strukture frazema, redu pojedinih frazemskih sastavnica i frazemskoj

Marija $\neq$ dastehen, als hätte man einen Stock (ein Lineal) verschluckt (usp. Matešić 1988: 278) u značenju 'usiljeno/ukočeno se držati/ponašati'). Ograničenost građe na rječničke izvore ukazuje samo na normativnu uporabu frazema.

4 Frazemska pozadinska slika ili značenjski/semantički talog unutarnja je slika koja motivira frazeološko značenje (v. više u Fink 1994: 72, 74).

5 Inačice istovjetnih nosivih sastavnica, ali različite morfosintaktičke strukture brojali smo kao jedan primjer. Više o strukturi i značenju frazema općenito usp. H. Burger, A. Buhofer, A. Sialm 1982: 23). 
pozadinskoj slici (usp. im Adamskostüm $\rightarrow$ u Adamovom kostimu; bei Petrus anklopfen $\rightarrow$ pokucati svetom Petru na vrata [...]).

\subsubsection{Nulta ekvivalencija}

Kod ovoga tipa ekvivalencije frazemi pokazuju strukturnu i leksemsku nepodudarnost frazemskih sastavnica i nepodudarnost frazemske pozadinske slike, odnosno nemaju ekvivalent u drugome jeziku, nego se prevode opisno ili doslovno da bi se shvatio njihov smisao: „Ponekad problem predstavljaju frazemi čije se sumativno značenje ne može nazrijeti iz značenja njegovih komponenti, a odgovarajući ekvivalent ne postoji u materinskom jeziku" (usp. Hrustić 2001: 79). Frazemske se različitosti vezuju uz posebnosti kultura, navika i iskustava naroda, odnosno jezičnih zajednica, zbog čega se frazemi i razlikuju u svojoj pozadinskoj slici od jezika do jezika (usp. den armen Judas singen $\neq \Theta \mathrm{u}$ značenju 'ismija(va)ti koga'; einen Uriasbrief überbringen $\neq \Theta$ u značenju 'donijeti komu nesretnu vijest' [...]).

\subsection{Rezultati istraživanja}

Potpunu ekvivalenciju, odnosno potpunu značenjsku, leksemsku i strukturnu podudarnost frazemskih sastavnica i podudarnost pozadinske slike, odnosno podudarnost na planu izraza i planu sadržaja, bilježimo u sljedećim primjerima:

1) sicher wie in Abrahams ${ }^{6}$ Schoß (razg.) = sigurno kao u Abrahamovu krilu

Značenje je frazema 'osjećati se sigurnim, zaštićenim'.

6 Podrijetlo: Evandelje po Luki $(\operatorname{Lk} 16,22)$. Značenje: „Äbraham (Àbram, Àvraam) m 1. v. 2. bibl. prvi praotac (patrijarh) Izraelaca, poštovan od židova, kršćana i muslimana kao začetnik svih monoteističkih religija; objavio mu se Bog (Jahve) s kojim se zavjetovao na savez (Stari zavjet); Bog je obećao Abrahamu da će njemu i njegovom narodu dati zemlju Kanaan (danas Izrael, Palestina), a Abraham se zavjetovao da će on i njegov narod štovati samo Jahvu kao svog i jedinog Boga; [...] hebr. 'abhrāhām: otac je uzvišen“" (usp. Hrvatski enciklopedijski rječnik (u daljnjem tekstu HER) A-Bez 2002: 8). V. i primjer (10) odnosno podnožnu bilješku 19 u radu. 
2) (a) geduldig wie Hiob ${ }^{7}$ = strpljiv kao Job

(b) der geduldige Hiob = strpljivi Job

Biblijska priča u kojoj Bog dopušta Sotoni da iskuša Jobovu vjeru motivirala je pozadinsku sliku frazema (2a) i (2b) u značenju 'jako strpljiv'. Njima se simbolizira neograničeno strpljenje koje se iskazuje u čekanju na neki ishod unatoč okolnostima koje su beznadne. $^{8}$

3) ein armer Lazarus $^{9}=$ ubogi Lazar

Sukladno podrijetlu frazema uporabit ćemo ga za osobu koja je jadna, bijedna, beznačajna, nad kojom ćemo se smilovati zbog njezina siromaštva ili bolesti.

4) wie Lots $^{10}$ Frau = kao Lotova žena

Za osobu ćemo reći da je 'kao Lotova žena' ako se u nekoj opasnoj situaciji bavi prošlošću umjesto da se okrene sadašnjosti i usmjeri na trenutačnu opasnost. Ponekad se uporabljuje i za onoga tko se uznemirava zbog svoje imovine ili za nekoga tko je preznatiželjan u nekoj opasnoj situaciji.

7 Podrijetlo: Knjiga o Jobu (Job 1,21). Značenje: „)öb $m$ 1. v. 2. a. bibl. pravedan i mudar čovjek (u istoimenoj biblijskoj knjizi) kojega Bog, preko sotone, stavlja na velike patnje iskušavajući njegovu vjeru, ali on sve podnosi i ostaje nepokolebljiv; b. pren. simbol čovjeka koji sve životne nedaće strpljivo podnosi [...] hebr. 'iyyōbh: omražen" (usp. HER Gra-J 2002: 361).

8 Hrvatski se ekvivalent uporabljuje s istovjetnim značenjem, ali kao dijalektalni frazem (usp. Menac-Mihalić 2003: 366).

9 Podrijetlo: Evanđelje po Luki (Lk 16, 19-31). Značenje: „Läzār (hebr. Eleàzar) 1. v. 2. iz Betanije bibl. brat Marijin i Martin, Isusov prijatelj kojega je uskrisio od mrtvih, 3. gubavac a. bibl. siromah koji je uzalud prosio pred vratima škrtog bogataša, b. pren. bogalj, prosjak [...] hebr. 'el(ë)'āzār: kojemu je Bog pomogao; u biblijskoj paraboli o bogatašu i prosjaku, bolesni prosjak" (usp. HER K-Ln 2002: 337).

10 Podrijetlo: Knjiga postanka (Post 19,26); Evanđelje po Luki $(L k 17,32)$. Značenje: „Löt $m$ bibl. nećak Abrahamov, jedini pravednik koji je zajedno s obitelji spašen za uništenja Sodome i Gomore; pri bijegu njegova se žena, usprkos zabrani, osvrnula i tako bila pretvorena u stup soli, hebr. lōṭ" (usp. HER Lo-Ner 2002: 17) i „I tko bude u polju, neka se ne okreće natrag. Sjetite se žene Lotove!“ (Lk 17,32). 


\section{5) alt wie Methusalem ${ }^{11}$ = star kao Metuzalem}

Frazem u značenju 'biti jako star' uporabit ćemo kada želimo ukazati na duboku starost neke osobe. ${ }^{12}$

6) (a) von Pontius zu Pilatus ${ }^{13}$ laufen (razg.) = ići od Poncija do Pilata (b) j-n von Pontius zu Pilatus schicken (razg.) = poslati/slati od Poncija do Pilata koga

Frazemi (6a) u značenju 'tražiti nešto, ići za ciljem' i (6b) u značenju 'poslati/slati koga na mnoga mjesta u mukotrpnoj (dugotrajnoj) potrazi za rješenjem čega; poslati/slati koga mnogim ljudima' referiraju se na proces protiv Isusa kada je Pilat poslao Isusa Herodu Antipi da ga ispita, a ovaj ga je uz porugu poslao nazad Pilatu, koji ga je nakon toga osudio na smrt na križu. Poncije je Pilat jedna te ista osoba, ali se dijeljenjem imena u frazemu spajaju polazište i cilj puta i shvaćaju se kao imena dviju osoba.

7) $\{$ ein $\}$ salomonisches ${ }^{14}$ Urteil = salomonski/a/o/i pravorijek/presuda/rješenje/sud

Salomon je od početka „glasovit“, poglavito zbog „valjanog odabira“, jer u Bibliji se „Jahve javi Salomonu noću u snu i reče: 'traži što da ti dam' Salamon odgovori... podaj svome sluzi pronicavo srce da može suditi tvom narodu, razlikovati dobro od zla" (1 Kralj

${ }_{11}$ Podrijetlo: Knjiga postanka (Post 5,27). Značenje: „Metùzalem $m$ 1. bibl. sin Henohov, doživio je 969 godina i tako postao legendarni najdugovječniji čovjek, 2. (metuzalem) razg. pejor. Stara osoba kojoj je vrijeme prošlo, vrlo stara i prestara osoba; drevni starac, onaj koji je u vrlo visokoj dobi [star kao ] [...] hebr. mëthūšelaḥ" (usp. HER Lo-Ner 2002: 157).

12 Pored istovjetnoga frazema u hrvatskome se uporabljuje i varijantni frazem star kao Biblija, koji bi se, međutim, zbog nepodudarnosti nosivih leksemskih sastavnica ubrajao u tip djelomične ekvivalencije.

${ }^{13}$ Podrijetlo: Evandelje po Ivanu, Evandelje po Mateju, Evanđelje po Luki. Značenje: „Pïlāt, Poncije peti rimski prokurator Judeje (26-36), prema novozavjetnim Evandeljima po Mateju i Luki, grub i licemjeran silnik koji je mimo propisa odobrio mučenje Isusa, a smrtnu presudu nad njim navodno odobrio pod pritiskom svjetine [pere ruke kao $\sim$ ne želi biti odgovoran] [...]" (usp. HER Pes-Pro 2002: 23).

14 Podrijetlo: Prva knjiga o Kraljevima. Značenje: „Sälamōn 1.v. 2. bibl.pov. najmlađi sin kralja Davida, treći kralj Izraela (10. st. pr. Kr.); unaprijedio je trgovinu, obogatio zemlju i sagradio jeruzalemski hram; kasniji su pisci Biblije slavili njegovu mudrost, pripisivali mu mudre izreke i knjige (Mudre izreke, Propovjednik, Pjesma nad pjesmama) koje su uglavnom napisane više stoljeća poslije njega [...] hebr. šëlomoh: njegov mir" (usp. HER Pro-Silj 2002: 252-253). 
3,49). Salomonova je mudrost ili umnost u brojnim starozavjetnim tekstovima istoznačna poslovičnoj mudrosti, a to znači da su svi frazemi koji su povezani sa Salomonovim imenom simbol mudrosti. ${ }^{15}$

8) ein ungläubiger Thomas ${ }^{16}=$ nevjerni Toma

Frazem ćemo uporabiti kada želimo opisati osobu koja je pretjerano 'nevjerna, sumnjičava'. Nevjernost koju, pak, simbolizira samo ime Toma dodatno je intenzivirana pridjevom nevjerni. Njegovo se biblijsko podrijetlo vezuje uz Ivanovo evanđelje koje govori o Isusovome prvom ukazanju svojim učenicima. Kada se Isus učenicima ukazao prvi put, Toma nije bio s njima. Nakon što su mu ostali ispričali što se dogodilo, on im odgovori: „Ako ne vidim na njegovim rukama biljeg čavala i ne stavim svoj prst $u$ mjesto čavala, ako ne stavim svoju ruku u njegov bok, neću vjerovati“ (Iv 20,25).

Djelomična (ne)podudarnost očituje se u morfosintaktičkoj, leksemskoj i tvorbenoj strukturi frazemskih (ne)nosivih sastavnica, redu pojedinih frazemskih sastavnica te frazemskoj pozadinskoj slici zadržavajući isto ili slično denotativno značenje. ${ }^{17}$

1) Wo ist dein Bruder Abel ${ }^{18}$ ? $\rightarrow$ Gdje ti je brat Abel?

U obama se jezicima frazem uporabljuje ako se osobu želi navesti na ispitivanje savjesti za odgovornost ili suodgovornost u smrti nedužne osobe. Nepodudarnost se frazema očituje u morfosintaktičkoj strukturi.

${ }_{15}$ Sve mudre izreke i ostale poslovične formulacije se u Salamonovim biblijskim knjigama nazivaju njegovim imenom (usp. Botica 1995: 126). Prema različitim inačicama imena kralja Salomona izvedeni su i različiti oblici posvojnoga pridjeva salomonski, salamonski, solomonski i solomunski (više u Opašić 2014: 192).

16 Podrijetlo: Evanđelje po Ivanu (Iv 20). Značenje: „Töma 1. v. [...] 4. Nevjerni bibl. Apostol, zvan i Blizanac, Kristov učenik koji nije htio povjerovati u uskrsnuće dok nije svojim očima vidio Kristove rane i ruke stavio na njih; nije povjerovao ni u Marijino uznesenje na nebo, dok mu nije bacila svoj pojas [...]" (usp. HER Tar-Viš 2002: 80-81).

${ }_{17}$ Koliko je bitno poznavanje tih različitosti, ukazuje i Hrustić kada kaže da „nepoznavanje ovakvih detalja može dovesti od netočnog prijevoda u drugi jezik zbog djelovanja interferencije" (2001: 70).

${ }_{18}$ Podrijetlo: Knjiga postanka (Post 4,9). Značenje: „Ábel $m$ 1. bibl. drugi sin Adama i Eve, ubio ga stariji brat Kain; 2. pren. nedužno ubijen čovjek, hebr. Hebhel“" (usp. HER A-Bez 2002: 4). 
2) in Abrahams Schoß eingehen $\rightarrow$ biti primljen/otići/preseliti se $u$ Abrahamovo krilo

Prema kršćanskomu vjerovanju nakon smrti ide se u pakao ili raj, ovisno o djelima i grijesima u zemaljskome životu: „Kad umrije siromah, odnesoše ga anđeli u krilo Abrahamovo. Umrije i bogataš te bude pokopan“ $(L k 16,22)$. U obama se jezicima frazem uporabljuje u značenju 'preminuti', odnosno aludira se na odlazak u Abrahamovo krilo, u krilo ${ }^{19}$ oca svih koji vjeruju, „mjesto odmora pravednika, mjesto bez boli, mjesto čekanja koje prethodi potpunoj sreći“ (usp. Rječnik biblijske kulture 1999: 2). Djelomična se nepodudarnost frazema očituje na planu izraza i to u različitosti glagolskih sastavnica.

3) im Adamskostüm ${ }^{20}$ (razg; pejor.) $\rightarrow$ u Adamovu kostimu

Frazem se u obama jezicima uporabljuje ako se želi ukazati na to da je osoba naga, bez odjeće: „A bijahu oboje goli - čovjek i njegova žena - ali ne osjećahu stida" (Post 2,25). Nepodudarnost se frazema očituje u tvorbenoj strukturi.

4) von Adam und Eva her verwandt $\rightarrow$ Adamovo koljeno

Budući da prema Bibliji svi ljudi potječu od prvoga ljudskog para, frazem se uporabljuje pejorativno ako se pojašnjava neka rodbinska veza koja se može naći tek nekada predaleko. U hrvatskome je ekvivalentu Adamovo koljeno ${ }^{21}$ razvidna nepodudarnost frazemske pozadinske slike i frazemskih sastavnica s ishodišnim frazemom.

19 Kod Židova krilo simbolizira počasno mjesto gostu pri objedu (usp. Opašić 2014: 189).

20 Podrijetlo: Knjiga postanka (Post 2 i 3); Poslanica Efežanima (Ef 4,22 ff). Značenje: „Àdam $m$ 1. bibl. prvi čovjek (prema knjizi Postanak) 2. opće ime za čovjek ili ljudski rod. [...] hebr. 'ādhām: (dosl.) čovjek êdhāmāh: zemlja (jer je Bog stvorio Adama od praha zemaljskoga)“ (usp. HER A-Bez 2002: 14). Adam i Eva su biblijski par koji se vrlo često javlja u frazemskim konstrukcijama. Simbol su početka čovječanstva, ali i prvoga grijeha. U frazemima se javljaju kako odvojeno tako i skupa.

${ }^{21}$ Usp. „[...] potomci Adamovi, čovjek kao pojedinac i svi ljudi kao zajednica jednog ishodišta“ (usp. HER A-Bez 2002: 14). 
5) bei Adam und Eva anfangen (razg.) $\rightarrow$ početi od Adama $i$ Eve U značenju 'početi od samog početka, sa svim potankostima', 'govoriti nadugo i naširoko' frazem se uporabljuje u pejorativnome obliku. ${ }^{22}$ Razvidna je nepodudarnost morfosintaktičke strukture.

6) von Adam und Eva \{ab\}stammen (razg.) $\rightarrow$ od Adama i Eve \{?\}

Frazem označuje da je nešto prastaro ili da je netko prestar i kao takav svima odavno poznat. Nepodudarnost se očituje u glagolskoj sastavnici koja je izostala u hrvatskome frazemu.

7) David ${ }^{23}$ gegen Goliath $\rightarrow$ borba Davida i Golijata

U biblijskoj je predaji David, još dok je bio pastir, iako malen i naoko slab, svojom snalažljivošću i spretnošću pobijedio diva Golijata. Frazem se uporabljuje kada se želi ukazati na borbu slabijega (obično pravednijega) s moćnijim (obično nepravednijim) protivnikom, odnosno na nepravednu borbu. Nepodudarnost se frazema očituje u leksemskoj strukturi nenosivih sastavnica i morfosintaktičkoj nosivih sastavnica.

8) David in der Rüstung Saulus ${ }^{24} \rightarrow$ David u Šaulovoj bojnoj opremi Frazem se uporabljuje ako je osoba za neki zadatak opremljena posebnom opremom, ali nije uvježbana u korištenju te opreme, te joj ona stoga više odnemaže nego pomaže (usp. Kraus 1993: 40). Iako frazem nije zabilježen u hrvatskoj frazeološkoj građi, pronašli smo potvrdu o njegovoj uporabi: „Često je ta Crkva bila kao David u Šaulovoj bojnoj opremi ..." (usp. Pervan 2006: 4). Nepodudarnost se frazema očituje u leksemskoj strukturi i redu sastavnica.

${ }_{22}$ U hrvatskome jeziku bilježimo i varijantni frazem istovjetna značenja, ali koji nije biblijskoga podrijetla, usp. početi od Kulina bana (usp. Matešić 1988: 252).

${ }^{23}$ Podrijetlo: Prva knjiga o Samuelu (1 Sam 17). Značenje: „Dàvid 1. v. 2. izraelski kralj (11. st. do poč. 10. st. pr. Kr.), pobijedio Filistejce i znatno ojačao kraljevstvo; u biblijskoj knjizi Psalmi; Davidu se pripisuje autorstvo 73 psalama (od ukupno 146) [...] hebr. dāwidh: drag, ljubljen“" (usp. HER Bež-Dog 2002: 267).

${ }^{24}$ „Šaul obuče Davida u svoju ratnu odoru, na glavu mu ustače mjedenu kacigu i stavi mu oklop. Pripasa Davidu svoj mač preko odore, ali David uzalud pokuša hodati, jer ne bijaše navikao, pa reče Šaulu: 'Ne mogu hodati u tome jer nisam navikao.' Zato sve skinu sa sebe“ (1 Sam 17, 38-40). 
9) im Evaskostüm ${ }^{25}$ (razg.; pejor.) $\rightarrow$ u Evinu kostimu

Evin (kao i Adamov) kostim simbolizira 'nagost' u obama jezicima. Različitost se frazema očituje u tvorbenoj strukturi frazemskih sastavnica.

10) eine Evastochter (razg.; pejor.) $\rightarrow$ Evina kći

Frazem se uporabljuje pejorativno ako se želi opisati neku 'djevojku s posebice zavodničkim ženskim šarmom'. Značenje se temelji na biblijskoj priči kada Adamova žena navodi Adama da pojede jabuku sa zabranjenoga stabla. Nepodudarnost se očituje u tvorbenoj strukturi frazema.

11) Evastöchter $\rightarrow$ Evino koljeno

Razvidna je nepodudarnost tvorbene i leksemske strukture frazema, ali i njegove pozadinske slike. Frazemom se aludira na 'potomstvo prvih ljudi kao praroditelja svim ljudima na zemlji' (usp. (14)).

12) ein Goliath ${ }^{26}$ sein $\rightarrow$ biti kao Golijat

Frazem se referira na biblijsku priču o borbi Davida i Golijata: „Iz filistejskih redova izađe jedan izazivač. Zvao se Golijat, a bio je iz Gata. Visok bijaše šest lakata i jedan pedalj" (1 Sam 17,4). Uporabljuje se kada se za osobu želi reći da je 'iznimno snažna, jaka'.

${ }_{25}$ Podrijetlo: Knjiga postanka. Značenje: „Éva 1. v. 2. žena Adamova, stvorena od njegova rebra, prema Bibliji (knjiga Postanak) [...] hebr. hawwāh: živuća" (usp. HER Doh-Gra 2002: 185).

26 Podrijetlo: Prva knjiga o Samuelu (1 Sam 17). Značenje: „Golijat $m$ 1. bibl. u Starom zavjetu div, najjači Filistejac kojeg je u dvoboju, kamenom iz praćke, ubio izraelski pastir, kasnije kralj David. 2. (golijat) ekspr. pren. jak, golem, snažan čovjek; ljudeskara, orijaš, gorostas, div; hebr. golyath: golem, veličanstven" (usp. HER Doh-Gra 2002: 360). 
13) eine lange Jeremiade ${ }^{27}$ anstimmen $\rightarrow$ biti pravi Jeremija

Njemački frazem sadrži nosivu sastavnicu Jeremiade što je izvedenica od osobnoga imena Jeremija, a simbolizira 'osobu koja se stalno žali ili jadikuje'. U hrvatskome smo, pak, naišli na frazemski lokalizam biti pravi Jeremija koji govori o stanju boležljivosti u kojem se osoba nalazi (usp. Menac-Mihalić 2003: 381).

14) (a) ein keuscher Joseph ${ }^{28} \rightarrow$ praviti se pravednim Josipom

(b) keutsch wie Joseph $\rightarrow$ praviti se pravednim Josipom

Frazemi (22a/22b) motivirani su biblijskom pričom u kojoj Josip, nakon što mu se ukazao anđeo, prihvaća trudnu Mariju, iako dijete nije bilo njegovo i mogao je biti izložen sramoti: „A Josip, muž njezin, pravedan, ne htjede je izvrgnuti sramoti." (usp. Mt 1 , 18-25). U hrvatskoj frazeologiji potvrđen je frazem praviti se pravednim Josipom u značenju 'praviti se nedužnim'. Nepodudarnost se frazema očituje u leksemskoj i morfosintaktičkoj strukturi.

15) Judaskuss ${ }^{29} \rightarrow$ Judin poljubac

Prema Evandeljima (usp. podnožnu bilješku 29) apostol Juda Iskariotski glavarima je svećeničkim rekao da će im izdati Isusa, a oni su mu kao nagradu obećali trideset srebrenjaka. Juda je sa zapovjednicima hramskoga redarstva dogovorio način kako će im

${ }_{27}$ Podrijetlo: Jeremija $(36,1-45,5)$. Značenje: „Jerèmija $m$ 1. v. 2. pov. bibl. jedan od četiriju velikih starozavjetnih proroka (o.628-583. pr. Kr.), pripisuje mu se Jeremijina knjiga u Starom zavjetu; prorok koji je prije prvoga pada Jeruzalema upozoravao na grijehe u vlastitom narodu zbog kojih mu prijeti propast; poslije razaranja Jeruzalema i odvođenja mnogih u ropstvo (586), oplakuje zlu sudbinu grada, zemlje i naroda; 3. (jeremija) pren. onaj koji se stalno žali, onaj koji stalno kuka [...] hebr. yirmëyāhū: Jahve je imenovao, oslobodio" (usp. HER Gra-J 2002: 353).

${ }_{28}$ Podrijetlo: Knjiga postanka; Evanđelje po Mateju (Job 8,6). Značenje: „Jòsip (Jósef) zast. 1. v. [...] 3. bibl. sin miljenik patrijarha Jakova i Lee: ljubomorna ga braća prodala kao roba u Egipat gdje nakon mnogo peripetija postaje ministar na faraonovu dvoru i provodi uspješne gospodarske mjere; za gladi u Kanaanu primio svoju braću, oprostio im, pa njih, oca i izgladnjele Izraelce naselio u Egipat [...] hebr. Yōṣēph: Jahve je pridodao" (usp. HER Gra-J 2002: 366-367). U Evanđelju po Mateju sveti je Josip opisan kao „pravedan“, (usp. Mt 1,19) u značenju krepostan i svet muž.

${ }_{29}$ Podrijetlo: Evandelje po Mateju (Mt 26, 14-16), Evandelje po Marku $(M k$ 14,10) i Evandelje po Luki (Lk 22, 1-6). Značenje: „Jûda $m$ bibl. 1. četvrti sin praoca Jakova i Lee, legendarni predak istoimenog izraelskog plemena [...] 4. (jûda) pren. a. pejor. Židov b. izdajica [...]“ (usp. HER Gra-J 2002: 369-370). 
dati znak: „Koga poljubim, taj je. Njega držite i odvedite oprezno“ (Mk 14,44). Frazemom se izražava ljubaznost koja prikriva loše i podle namjere. Različitost se frazema očituje u tvorbenoj strukturi.

16) Judaslohn $\rightarrow$ Judin novac

Frazem simbolizira 'novac za koji se tko prodaje kao što je Juda prodao Isusa' ili 'za koji čini prljave usluge kome'. Razlikuju se po tvorbenoj strukturi. Bilježimo i sljedeće inačice u hrvatskome: Judina plaća (nagrada, para), Judine škude.

17) das Kainszeichen haben/tragen $\rightarrow$ imati/nositi Ka(j)inov znak $\{z ̌ i g\}$

Frazem se uporabljuje u prenesenome značenju 'da je netko doživotno okarakteriziran ubojicom' i kao takav razlikuje se od izraza u Bibliji: „A Jahve mu reče: 'Ne! Nego tko ubije Kajina, sedmerostruka osveta na njemu će se izvršiti!' I Jahve stavi znak na Kajina, da ga tko, našavši ga, ne ubije" (Post 4,15). Dakle, ne radi se o označavanju krivca, već o znaku koji zaštićuje kako bi se spriječilo širenje krvne osvete. Nepodudarnost se frazema očituje u tvorbenoj strukturi i frazemskim sastavnicama.

18) (a) einen von Pilatus zu Herodes schicken

(b) einen von Herodes zu Pilatus schicken $\rightarrow$ slati od Poncija do Pilata koga

Frazemi (21a/21b) istovjetna su inačica frazema (6). U hrvatskome je, pak, ispalo ime Heroda.

19) Peterspfennig ${ }^{30} \rightarrow$ Petrov novčić

Uz razvidnu različitost tvorbene strukture frazem se $\mathrm{u}$ obama jezicima uporabljuje $u$ istome značenju 'Petrov novčić, novčani

${ }^{30}$ „Pètar 1. v. 2. Sv. apostol, Simon (Šimon), sin Jonin, galilejski ribar, prvi od 12 apostola; nakon Isusove smrti osnovao prvu kršćansku zajednicu u Jeruzalemu, zatim u Rimu, gdje je bio i njen prvi biskup i prvi papa; umro mučeničkom smrću za vrijeme prvoga progona kršćana 0.67 u Rimu; prema legendi, bio je razapet na križ, ali naglavce jer se nije smatrao dostojnim da umre poput Krista; pripisuju mu se dvije poslanice [...] grč. pétros: stijena" (usp. HER Pes-Pro 2002: 7-8). 
godišnji prinos kat. vjernika rimskom biskupu kao nasljedniku sv. Petra' $^{131}$.

\section{2o) bei Petrus anklopfen (ugs.) $\rightarrow$ pokucati svetom Petru na vrata}

Frazem se uporabljuje u značenju 'umrijeti'. Prema narodnome shvaćanju, sv. Petru pripisuje se uloga čuvara vrata Kraljevstva nebeskoga, kamo kršćani odlaze ili u raj ili u pakao. Razvidna je nepodudarnost frazemskih sastavnica uz očuvanu frazemsku pozadinsku sliku u obama jezicima.

21) (a) Salomos Pantoffeln \{geerbt\} $\rightarrow$ mudar kao Salomon

(b) der zweite Salomo $\rightarrow$ mudar kao Salomon

(c) die Weisheit Salomos $\rightarrow$ Salomonova umnost \{mudrost $\}$

Da je osoba 'jako mudra' ili 'donosi neku mudru odluku', u njemačkome se izražava frazemima (27a), (27b) i (27c). U hrvatskim se ekvivalentima bilježi različitost frazemskih sastavnica (27a), (27b), red frazemskih sastavnica (27c) i frazemske pozadinske slike (27a) i (27b).

22) aus einem Saulus zu einem/zum Paulus ${ }^{32}$ werden = postati od Savla Pavao

Značenje je frazema 'posve se preobratiti, postati drugi čovjek'. Razvidna je morfosintaktička nepodudarnost frazemskih sastavnica. U hrvatskome bilježimo i varijantni frazem od Salva učiniti Pavla.

Nepodudarnost (ne)nosivih leksemskih sastavnica i različitost frazemske pozadinske slike, odnosno nepostojanje ekvivalentnoga frazema u analiziranim rječnicima jezika cilja, bilježimo u sljedećim primjerima ${ }^{33}$ :

${ }_{31}$ Usp. „Petrov novčić“, Hrvatski leksikon, <www.hrleksikon.info/definicija/petrov-novcic. html>, (2. I. 2019.)

${ }^{32}$ Podrijetlo: Djela apostolska 9. Značenje: Savao - biblijska priča iz Djela apostolskih govori o Savlovu preobraćenju. Nakon preobraćenja Savle mijenja ime u Pavao. „Pävao 〈G Pâvla〉 1. v. 2. Sv. (između 5. i 8. - o. 67), apostol, rodom iz Tarza (u Maloj Aziji), prauzor kršćanskog misionarstva; shvatio da se kršćanstvo može odvojiti od roditeljskog židovstva, smatra se osnivačem kršćanstva kao crkve; napisao 14 poslanica, pogubljen u Rimu [...]“ (usp. HER Nes-Per 2002: 299-300).

33 Prijevod frazema jezika polaznika potječe od autora priloga. 
23) Bin ich denn der Hüter meines Bruders Abel? ${ }^{34} \neq \Theta$

Frazem se uporabljuje kada se osoba pitanjem želi distancirati od neke odgovornosti za koju se podrazumijeva da je njezina i kada se želi reći kako je nije briga za nekoga ili nešto, dakle u prenesenome značenju 'zar sam ja odgovoran za to, otkud ja to da znam'. Iako hrvatska rječnička građa ne bilježi frazem, možemo ga doslovno prevesti i rabiti u istome značenju: 'Zar sam ja čuvar brata svojega?', uz izostavljanje imena.

24) in Abrahams Wurstkessel kommen/sitzen (vulg. vojn.) $\neq \Theta$

Frazem se jezika polaznika uporabljuje u vojničkome žargonu i to s prizvukom vulgarnosti u značenju 'poginuti u ratu; nalaziti se u paklu bojišta; umrijeti', dok hrvatska rječnička građa ne bilježi isti.

25) noch in Abrahams Wurstkessel sein (razg.) $\neq 0$

Frazem se uporabljuje u razgovornome jeziku. Značenjski 'ne biti još rođen' potpuno je suprotan frazemu in Abrahams Wurstkessel kommen i označava vrijeme prije rođenja. Hrvatska rječnička građa ne bilježi frazem.

26) Vater Abraham sehen $\neq \Theta$

Značenje je frazema 'star kao Biblija (fam.), bio je sekretar kada se pisala Biblija (stud.), veoma je star, star je kao Metuzalem'. Frazem se vezuje uz sumnjičavo pitanje Židova upućeno Isusu kao biblijsku pozadinu: „Du bist noch nicht fünfzig Jahre und hast Abraham gesehen?" (Iv 8,57). ${ }^{35}$

27) Adam, wo bist $d u ? \neq \Theta$

Nakon što su Adam i Eva u raju jeli sa stabla u vrtu, skrili su se od Boga, ali Bog upita: „Adame, gdje si?“ (Post 3,96). Taj se frazem u njemačkome jeziku uporabljuje za osobu koja se želi povući iz nekoga društva ili želi izbjeći odgovornost. Budući da raspoloži-

Podrijetlo: Post 4, 8-9.

Frazem den Abraham sehen uporabljuje se u značenju '(pro)slaviti 5o. rođendan'. „Abrahamstag" kao oznaka za 5o. rođendan rasprostranjena je prije svega u Gornjoj Šleziji i području Ruhra. 
va hrvatska rječnička građa ne bilježi frazem, doslovni prijevod 'Adame, gdje si?' držimo prihvatljivim.

28) der alte Adam im Menschen $\neq \Theta$

Frazem aludira na Adamovu pogrešku, odnosno grijeh koji je počinio kada je sa svojom ženom jeo iz Edenskoga vrta. Simblom je „nepopravljivoga grijeha u nama“ (Kraus 1993: 12), odnosno 'praroditeljskoga grijeha, starih navika, starih slabosti'. Hrvatska rječnička građa ne bilježi frazem kao takav.

29) (a) einen neuen Adam anziehen (poet.) $\neq \Theta$

(b) den alten Adam ausziehen ${ }^{36}$ (poet.) $\neq \Theta$

Nastanak frazema nalazimo u biblijskoj Poslanici Efežanima (Ef 4,22): „Velim i zaklinjem da sa sebe skinete i odložite staroga čovjeka koji pripada prijašnjem načinu života, čovjeka koji u varavim požudama ide u propast, te da se iz dana u dan obnavljate duhom u kojem mislite i da se obučete u novog čovjeka, stvorena na sliku Božju u istinskoj pravednosti i svetosti." Hrvatski je ekvivalent izostao. Opisno možemo govoriti o „starom“ i „novom čovjeku" u značenju 'raskrstiti s prošlošću, postati novim, boljim čovjekom'.

30) seit Adams Zeiten/Tagen (razg.) $\neq \Theta$

Sukladno kršćanskome vjerovanju, svijet počinje s Adamom. Iako konzultirana hrvatska rječnička građa ne bilježi frazem, držimo da je za isti prihvatljiv doslovni prijevod 'od Adamovog vreme$\mathrm{na}^{\prime} \cdot{ }^{37}$

${ }_{36}$ Budući da inačice simboliziraju istovjetno značenje uz razvidnu zamjenu antonima neu $\rightarrow$ alt, anziehen $\rightarrow$ ausziehen, brojimo ih kao jedan primjer u korpusnoj građi.

37 Frazemi jezika cilja od pamtivijeka (seit Menschengedenken), otkako je svijeta $i$ vijeka (seit die Welt besteht) ne sadrže sastavnicu imena Adam u jeziku polazniku te ne mogu biti ekvivalent frazema seit Adamszeiten/Tagen. 
31) ein Benjamin ${ }^{38} \operatorname{sein} \neq \Theta$

Iz priče o Josipu i njegovoj braći (Post 42,4) dade se zaključiti zašto je ime Benjamin postalo simbolom najmlađega, omiljenog djeteta u obitelji: „Benjamina, Josipova pravog brata, Jakov ne posla $\mathrm{s}$ ostalima. 'Da ga ne bi zadesila kakva nesreća' govorio je." Budući da frazem kao takav nije zabilježen u raspoloživoj hrvatskoj rječničkoj građi, predlažemo doslovni prijevod 'biti kao Benjamin' ili opisni 'kao najmlađi biti miljenik u obitelji'.

32) wie David und Jonathan $\neq \Theta$

Kada se David iz dvoboja protiv Golijata vratio na dvor kralja Šaula, blisko se sprijateljio s njegovim sinom i nasljednikom Jonatanom. Tada se „Jonatanova duša prikloni Davidovoj duši i Jonatan ga zavolje kao samoga sebe" (1 Sam 18,1). Ta je povezanost izdržala svađu između Davida i Jonatanova oca Šaula te samoga Jonatana: „Žao mi je tebe, brate, Jonatane! Kako li mi drag bijaše ti veoma! Ljubav tvoja bješe meni još od ženske čudesnija" (2 Sam 1,26). U analiziranoj rječničkoj građi nije zabilježen hrvatski ekvivalent biblijskoga podrijetla, stoga predlažemo doslovni prijevod 'kao David i Jonatan' aludirajući na odano prijateljstvo.

33) der Rat des Gamaliel ${ }^{39} \neq \Theta$

Ime se Gamalilejovo ne uporabljuje u hrvatskoj frazeologiji. Frazem jezika polaznika u doslovnome prijevodu 'Gamalilejov savjet' uporabit će se kada se želi ukazati na to da novomu ne treba ići

${ }_{38}$ Podrijetlo: Knjiga postanka (Post 42). Značenje: „Bénjamin 1. a. bibl. najmlađi sin patrijarha Jakoba i Rahele, Jakobov ljubimac; predak istoimenog plemena; b. najmlađe dijete; mezimac, ljubimac [...] hebr. bēn-yāmīn" (usp. HER A-Bez 2002: 277). U svezi s tim usp. i sljedeće: „Wenn uns eine Mutter oder ein Vater ihren Sohn mit den Worten vorstellt, das ist ,unser Benjamin', dann muss damit nicht gemeint sein, dass dieses Kinde den Vornamen ,Benjamin trägt. Vielmehr könnten die Eltern damit eher zum Ausdruck bringen wollen, dass es sich bei dem Kind um den ,Benjamin in der Familie', also um das jüngste Kind in der Familie handelt" (usp. Buchna 2003: 61).

39 Podrijetlo: Djela apostolska ( $D j$ 22,3; Dj 5, 38-40). Značenje: Gamalilej je inače u Bibliji bio učitelj Farizejaca i učitelj apostola Petra. Nakon što su Apostoli nakon Isusova uskrsnuća uhićeni i dovedeni pred Veliko vijeće u Jeruzalemu zbog svojih propovijedi, Gamalilej se suprostavio smrtnoj presudi rekavši: „A za ovo sada, kažem vam: prođite se tih ljudi i pustite ih! Jer ako njihov pothvat, ili njihovo djelo, potječe od ljudi, propast će, a ako potječe zbilja od Boga, nećete ga moći uništiti“ ( $D j$ 5, 27-39). 
s predrasudama i zabranom, već sačekati dok se ne vidi da je to novo uistinu i ispravno.

34) (a) $j$-m eine Hiobsbotschaft bringen $\neq \Theta$

(b) eine Hiobspost bringen $\neq \Theta$

Frazemske inačice nisu zabilježene u konzultiranoj hrvatskoj građi. Aludirajući na Joba (usp. podnožnu bilješku 6), biblijskoga lika kojega na početku istoimene biblijske priče pogađa nesreća za nesrećom te gubi bogatstvo, djecu i zdravlje, a da pri tomu ne prestaje slaviti Boga (usp. "Jahve dao, Jahve oduzeo!" (Job 1,21)). Simboliziraju strašnu, groznu vijest. Obje se inačice uporabljuju u značenju 'donijeti komu strašnu/groznu/tužnu/žalosnu vijest'.

35) der billige Jakob ${ }^{40} \neq \Theta$

Frazem se jezika polaznika uporabljuje u dva značenja 'trgovca na sajmu koji glasno nudi svoju robu' i 'prevareni, obmanuti mali čovjek'. Nezabilježenost istoga u analiziranoj hrvatskoj rječničkoj građi upotpunit ćemo sukladno kontekstu u kojemu se uporabljuje prijevodom 'ulični prodavač' (za prvo značenje) i već navedenim drugim opisnim značenjem.

36) (nicht) der wahre Jakob sein $\neq \Theta$

Frazem se uporabljuje kada za nekoga ili nešto želimo reći da je 'onaj pravi/ono pravo, da je to onaj kojeg tražimo, onaj koji je na određenome polju najbolji'.

37) Josephsehe führen $\neq \Theta$

Frazemom se aludira na bračni odnos između Marije, Isusove majke i njezina muža Josipa ${ }^{41}$ Frazem kao takav nije potvrđen u analiziranoj hrvatskoj rječničkoj građi. Može se doslovno prevesti

40 Podrijetlo: Djela apostolska (Dj 12,2). Značenje: „Jäkov (Jäkob) 1. v. 2. bibl. treći starozavjetni praotac, unuk Abrahama i Sare, drugi sin Izaka i Rebeke, blizanac Ezava, otac 12 sinova koji su postali rodonačelnici 12 izraelskih plemena; prema Jahvinoj zapovijedi uzeo ime Izrael, koje se kasnije prenijelo na cijeli narod i na državu [...] hebr. ya ${ }^{\text {th }}$ qobh: otvoren“ (usp. HER Gra-J 324.-325.).

${ }^{41}$ Kršćanska tradicija pretpostavlja da njih dvoje nikada nisu imali spolni odnos. Ponekad se takva vrsta braka naziva i „anđeoskim brakom“, prema riječima Isusa u Evanđelju po Mateju: „O uskrsnuću niti će se ženiti niti udavati, nego će biti kao nebeski anđeli“ (Mt 29,30). 
kao 'voditi Josipov brak' u značenju 'imati platonski odnos prema kome'.

38) (a) den armen Judas singen (zast.) $\neq \Theta$

(b) jemandem den Judas singen $\neq \Theta$

Frazemske inačice ukazuju na istovjetno frazeološko značenje, odnosno na nešto loše, negativno u značenju 'ismija(va)ti nekoga', jer Judino ime među kršćanima budi reakciju osude i odbijanja. Frazem nije potvrđen $u$ analiziranoj hrvatskoj rječničkoj građi.

39) wie Kain ${ }^{42}$ und Abel $\neq \Theta$

Frazem je motiviran biblijskom pričom u kojoj je Adamov prvi sin Kain ubio brata Abela jer je Jahve prihvatio Abelovu žrtvu, a ne njegovu (Post 4). Poanta je priče vjerojatno u tome da među dvojicom braće ipak postoji razlika na koju je Kain reagirao s ljubomorom. Time se opisuje kako ljubomora, inače čest fenomen među ljudima, izazvana prividnim ili stvarnim razlikama, može dovesti do ubojstva ako se na vrijeme i na pravi način ne savlada (usp. Kraus 1993: 110). Budući da je simbolika priče o dvojici braće općepoznata, frazem prevodimo doslovno 'kao Ka(j)in i Abel'. Ako, dakle, za neke osobe kažemo da su 'kao Kain i Abel', onda su oni simbolom ubojice i njegove nevine žrtve.

40)Krethi und Plethi ${ }^{43}$ (razg.) $\neq$ Petar $i$ Pavao

Frazem u značenju 'bilo tko, svatko' u hrvatskoj je rječničkoj građi potvrđen kao frazem Petar i Pavao. Razvidna je nepodudarnost nosivih sastavnica i pozadinske slike.

${ }_{42}$ Podrijetlo: Knjiga postanka. Značenje: „Kàin (Kàjin) $m$ 1. bibl. prvi sin Adama i Eve; zbog ljubomore ubio je svog brata Abela; prema biblijskoj Knjizi postanka prvi zločin među ljudima na Zemlji; 2. pren. bratoubojica, hebr. qayin: posjed" (usp. HER K-Ln 2002: 12).

43 Podrijetlo: Stari zavjet, Druga knjiga o Samuelu (2 Sam 8,18). Značenje: „grč. doslovno Krećani i Filistejci, no upotrebljava se kao izraz za 'miješano' društvo, ološ, bagažu (po Bibliji su Krećani i Filistejci bili tjelesni stražari kralja Davida [...]" (usp. Klaić 1990: 752). Prvotno se mislilo da je izraz motiviran tjelesnim stražarima u službi kralja Davida koji su bili strani plaćenici različita roda i neomiljeni u narodu, a u novije vrijeme da se riječi odnose na osobine vodećih ljudi u Davidovoj tjelesnoj straži (usp. krethi 'ubiti' i plethi 'odjuriti, othitati'), pa su Kreti tako krvnici, a Filistejci brzi glasnici koji su prenosili kraljeve naredbe. 
41) ein langer $\operatorname{Laban}^{44} \neq \Theta$

Frazem u značenju 'vrlo visok i mršav čovjek, dugonja/dugajlila' nije kao takav zabilježen u hrvatskoj rječničkoj građi našega korpusa. Iako biblijski Laban nikada nije opisivan kao izrazito visok, frazemom se vjerojatno aludira na dugo vrijeme koje je Jakov morao provesti kod Labana radeći.

42) Marthadienste $^{45} \neq \Theta$

Frazem jezika polaznika u doslovnome prijevodu 'Martini poslovi' nije potvrđen $u$ analiziranoj hrvatskoj rječničkoj građi. Uporabit će se kada se misli na sve one „sitne“ kućanske poslove koji su bezvrijedni u usporedbi sa "visoko“ cijenjenim intelektualnim.

43) bei j-m ist Matthä $i^{46}$ am Letzten $\neq \Theta$

Ovaj frazem nije potvrđen u hrvatskoj rječničkoj građi našega korpusa. Opisni prijevodi 'dani su mu odbrojani; došao mu je kraj; nema ni prebijene pare' aludiraju na kraj ili propast, financijsku ili neke druge vrste, $u$ životu kao što i Matejevo evanđelje (Mt 28,20), aludirajući na kraj svijeta, završava Isusovim riječima: „Ja sam s vama u sve vrijeme do svršetka svijeta". Uporabljuje se i bezlično es ist (noch nicht) Matthäi (razg.) u značenju 'došao je kraj, svršeno je', odnosno 'ima još spasa, nije sve propalo'.

44 „Làban $m$ bibl. Aramejac, prepredeni stočar u Haranu (današnja Sirija), Jakovljev ujak, kod kojeg je Jakov morao služiti dva puta po sedam godina da bi mogao oženiti najprije neželjenu Labanovu kćer Leu, zatim željenu Rahelu [...] hebr. lābhān: bijel“" (usp. HER K-Ln 2002: 311). Spominje se u knjizi Post 29, 1-30.

45 Podrijetlo: Evanđelje po Luki (Lk 10, 38-42). Značenje: Marta je ženski lik iz Biblije, Marijina sestra, a o njoj se govori u Lukinu evanđelju. Isus je jednom svratio kod žene koja se zvala Marta. Njezina sestra Marija „sjede do nogu Gospodinovih i slušaše riječ njegovu”, a Marta je za to vrijeme obavljala kućanske poslove.

46 Podrijetlo: Evanđelje po Mateju (Mt 28,20). Značenje: „Màtej 1. v. 2. Sv. (1. st.), carinik, zatim pozvan u zbor dvanaestorice apostola, zvan i Levi; prvi evanđelist, iako suvremena biblijska egzegeza drži Evanđelje po Marku najstarijim (o.7o) [...]“ (usp. HER Lo-Ner 109-110). Prvotno je izraz značio kraj svijeta, a kasnije se odnosio na pojedinca koji se nalazio u bezizlaznoj situaciji. 
44)Kalb Moses $^{47} \neq \Theta$

Frazem je motiviran biblijskom pričom o zlatnome teletu ${ }^{48}$, a uporabljuje se u značenju 'nespretan, glup čovjek (razg.)'. Analizirana hrvatska rječnička građa ne bilježi ga.

45) darauf losgehen wie Paulus auf die Korinther (arh.) $\neq \Theta$

Podrijetlo se frazema jezika polaznika u značenju 'zasuti nekoga prijekorima' vezuje uz biblijske poslanice Korinćanima ${ }^{49} \mathrm{u}$ kojima je sv. Pavao nagonio Korinćane da prijeđu na kršćanstvo. Analizirana hrvatska rječnička građa ne bilježi frazem.

46) die Pilatusfrage stellen $\neq \Theta$

To se pitanje postavlja ako se želi naglasiti sumnja koja se odnosi na čovjekovu moć spoznaje. ${ }^{50}$ Frazemski ekvivalent u značenju 'postaviti Pilatovo pitanje / Što je istina?' nije zabilježen u hrvatskoj rječničkoj građi našega korpusa.

47) Wie kommt Saul unter die Propheten? $\neq \Theta$

Značenje je frazema 'slučajno se negdje naći' (o biblijskome podrijetlu usp. podnožnu bilješku 32). Hrvatska frazeološka građa bilježi frazem dospjeti kao Pilat u Vjerovanje / naći se kao Pilat u Vjerovanju. Budući da je u njegovoj pozadinskoj slici slučajno spominjanje Pilatova imena u molitivi Apostolsko vjerovanje, a ne biblijski tekst, frazem se ne bi mogao smatrati biblizmom (usp. Opašić 2014: 197).

47 „Mójsije 1. v. 2. bibl. vizionar, zakonodavac i vođa koji je Izraelce izveo iz egipatskog sužanjstva i poveo u Zemlju obećanu, koju je nakon 40-godišnjeg lutanja pustinjom tek pred kraj života iz daljine nejasno vidio i nikad u nju nije stupio; prema bibl. knjizi Izlazak Bog mu je na Sinajskom brdu predao ploče s deset zapovjedi, koje su u Mojsijevoj interpretaciji i daljnjoj razradi postale i do danas ostale etičkim temeljima svih monoteističkih religija i judeokršćanske (europske, danas i američke) civilizacije [...] hebr. Mošeh“ (usp. HER Lo-Ner 2002: 213).

48 Zlatno tele simbolizira novac i bogatstvo i referira se na biblijsko podrijetlo Knjiga Izlaska 32, 1-35. Dok je Mojsije na brdu Sinaj primao 1o Božjih zapovjedi, izraelski je narod zatražio od Arona da im napravi boga kojemu bi se mogli klanjati. Aron je uzeo zlatni nakit od naroda i napravio zlatno tele kojemu je narod onda prinosio žrtvu i klanjao se.

49 Podrijetlo: Novi zavjet, Poslanice apostola Pavla: 1. Korinćanima i 2. Korinćanima.

5o Pilat i Isus $(I v 18,38)$ razgovarali su o Isusovu kraljevstvu i njegovoj ulozi kao svjedoku istine. Nakon cijeloga razgovora Pilat Isusu postavlja pitanje: „Što je istina?“, a odmah potom izlazi pred narod i kaže: „Ja ne nalazim na njemu nikakve krivnje." 
48) einen Uriasbrief überbringen $n^{51} \neq \Theta$

Frazem u značenju 'donijeti nesretnu vijest komu, ubiti glasnika', koji hrvatska rječnička građa ne bilježi, uporabit ćemo ako želimo kazati da je nesretna vijest pogubna za njezina donositelja, odnosno označava glasnikovu nesreću.

\section{Zaključak}

Od ukupno 56 frazema s biblijskim osobnim imenom kao sastavnicom u njemačkome - u hrvatskim ekvivalentima bilježimo 30 frazema s biblijskim osobnim imenom kao sastavnicom (= 5,35 \%). Potpunu ekvivalenciju zabilježili smo u 8 hrvatskih frazema $(=1,44 \%)$, djelomičnu u 22 hrvatska frazema (= 3,92\%), a za 26 frazema iz korpusa nultu ekvivalenciju (= 4,64\%). Sukladno očekivanjima, veći je broj frazema (njih 30) s biblijskim osobnim imenom kao sastavnicom koji pokazuju potpunu ili djelomičnu podudarnost leksemske i morfosintaktičke strukture uz istovjetnost frazeološkoga značenja, što je i razumljivo jer je kao izvor poslužila Biblija. Neočekivano je, međutim, velik broj frazema koji nisu zabilježeni u hrvatskoj rječničkoj građi našega korpusa, iako se u biblijskim tekstovima često nalaze doslovni prijevodi. U obama je jezicima najproduktivnije ime Adam. Zakonitosti prema kojima se neko ime pojavljuje, a neko ne, u frazeologiji nažalost još nisu dovoljno istražene.

U korpusnoj građi nije zabilježen nijedan primjer „lažnih prijatelja“, odnosno frazema koji su istovjetne leksičke strukture, ali različita frazeološkog značenja. Razlog tomu nalazimo u zajedničkome biblijskom podrijetlu frazema.

${ }^{51}$ Podrijetlo: Druga knjiga o Samuelu (2 Sam 11, 14-15. Značenje: Urija je biblijski lik, muž Bat-Šebin, hetitski plaćenik u službi izraelskoga kralja Davida. Kako bi se domogao njegove žene, David ga šalje svomu glavnom vojskovođi Joabu s pismom u kojem mu naređuje da postavi Uriju na takvo mjesto u bitci gdje će sigurno poginuti. Urija pobiga u bitci, a David ženi Bat-Šebu. Davidovo dvostruko nedjelo osuđuje prorok Natan. 


\section{Izvori}

- Die Bibel, Altes und Neues Testament, Einheitsübersetzung (1980) Herder Verlag, Freiburg - Basel - Wien.

\section{Rječnici}

- Anić, Vladimir (2004) Rječnik hrvatskoga jezika, Novi liber, Zagreb.

- Cvitković, Ivan (2005) Rječnik religijskih pojmova, drugo dopunjeno i prošireno izdanje, DES, Sarajevo.

- Duden (1992) Redewendungen und sprichwörtliche Redensarten, sv. 11, Dudenverlag, Mannheim - Leipzig - Wien - Zürich.

- Duden (1993) Das große Wörterbuch der deutschen Sprache in 8 Bänden, Dudenverlag, Mannheim - Leipzig - Wien - Zürich.

- Hansen-Kokoruš, Renate - Matešić, Josip - Pečur-MedinGER, ZRINKA - ZNIKA, MARIJA (2005) Njemačko-hrvatski univerzalni rječnik, Nakladni zavod Globus i Institut za hrvatski jezik i jezikoslovlje, Zagreb.

- Hrvatski Enciklopedijski Rječnik (2002) sv. 1-12, Leksikografski zavod Miroslav Krleža, Zagreb.

- Klaić, Bratoljub (1990) Rječnik stranih riječi A-Ž, Nakladni za$\operatorname{vod} \mathrm{MH}$, Zagreb.

- Kraus, Heinrich (1993) Geflügelte Bibelworte. Das Lexikon biblischer Redensarten, Beck, München.

- MateŠIĆ, JosıP (1982) Frazeološki rječnik hrvatskoga ili srpskoga jezika, Školska knjiga, Zagreb.

- MATEŠIĆ, Josıp i dr. (1998) Hrvatsko-njemački frazeološki rječnik, NZMH - Verlag Otto Sagner, Zagreb - München.

- Menac, Antica - Fink Arsovski, Željka - Venturin, RadoMIR (2003) Hrvatski frazeološki rječnik, Naklada Ljevak, Zagreb. 
- Mikić, Pavao - Gojmerac, Mirko (2011) Hrvatsko-njemački religijski rječnik/Religionswörterbuch Kroatisch-Deutsch, Naklada Slap, Zagreb.

- Mikić, Pavao - Gojmerac, Mirko (2017) Njemačko-hrvatski religijski rječnik/Religionswörterbuch Deutsch-Kroatisch, Naklada Slap, Zagreb.

- Mrazović, Pavica - Primorac, Ružica (1981) Njemačko-srpskohrvatski frazeološki rječnik, Narodna knjiga, Beograd.

- Rječnik biblijske kulture (1999) AGM, Zagreb.

- RöHRICH, Lutz (1995) Lexikon der sprichwörtlichen Redensarten. 5 Bände, Herder Spectrum Verlag, Freiburg.

- Schäfer, Heinz (1998) Biblische Redensarten und Sprichwörter. 3000 Fundstellen aus der Bibel, Dt. Bibelges, Stuttgart.

- Wahrig, Gerhard (2001) Deutsches Wörterbuch, Bertelsmann Lexikon Verlag, Gütersloh - München.

\section{Elektronički izvori}

- Hrvatski jezični portal. <http://hjp.srce.hr/>

- Aphorismen-Archiv, http://aphorismen-archiv.de/index_z. php?id=12577

\section{Literatura}

- Babić, Stjepan (2005) „Uz članak o Salomonu ili Solomunu“, Je$z i k$, Zagreb, god. LII, br. 2, str. 69-71.

- Botica, Stipe (1995) Biblija i hrvatska kulturna tradicija, Vlastita naklada, Zagreb.

- Buchna, Jörg (2003) Alle Jubeljahre ist nicht der wahre Jakob. Biblische Redewendungen, Selbstverlag, Norden.

- Burger, Harald - Buhofer, Annelies - Sialm, Ambros (1982) Handbuch der Phraseologie, Walter de Gruyter, Berlin. 
- Fink, ŽEljka (1994) Adjektivni frazeologizmi u ruskom i hrvatskom jeziku, doktorska disertacija, Filozofski fakultet Sveučilišta u Zagrebu, Zagreb.

- Fink, ŽEljka (200o) „Tipovi frazema - fonetskih riječi“, Riječki filološki dani, Rijeka, br. 3, str. 94-95.

- Fink-Arsovski, Željka (2002) Poredbena frazeologija: pogled izvana $i$ iznutra, FF press, Zagreb.

- Fleischer,Wolfgang ( $\left.{ }^{2} 1997\right)$ Phraseologie der deutschen Gegenwartssprache, Niemeyer, Tübingen.

- Földes, Csaba (1996) Deutsche Phraseologie kontrastiv. Intraund interlinguale Zugänge, Groos, Heidelberg.

- Hrustić, Meliha (2001) Kontrastivna analiza frazeoloških izraza sa komponentom Kopf/glava u njemačkom i u B/H/S jeziku, OFF-SET, Tuzla.

- Ivanetić, Nada - Karlavaris-Bremer, Ute (1994) Od Savla učiniti Pavla, o značenju $i$ asocijativnom potencijalu jedne fraze, Ekonomski fakultet, Rijeka.

- Kolenić, Ljiljana (1998) Riječ o riječima, Matica hrvatska, Osijek.

- Koller, Werner (2011) Einführung in die Übersetzungswissenschaft, A. Francke Verlag, Tübingen.

- Marinčić, SenKa (2006) „Zu den Adam-Eva-Phrasemfügungen im Deutschen und Kroatischen“, Mostariensia, Mostar, br. 23, str. 115-127.

- MateŠIĆ, Josip (1997) „Eigennamen in der Phraseologie am Beispiel der kroatischen Sprache“, Folia Onomatica Croatica, Zagreb, br. 6, str. 139-145.

- Menac, Antica (2007) Hrvatska frazeologija, Knjiga d.o.o., Zagreb.

- MenaC, Antica (1978) „Neka pitanja u vezi s klasifikacijom frazeologije“, Filologija, Zagreb, br. 8, str. 219-266. 
- Menac-Mihalić, Mira (2003) „Hrvatski dijalektni frazemi s antroponimom kao sastavnicom", Folia onomastica croatica, Zagreb, br. 12.13, str. 361-385.

- Opašıć, Maja (2014) „Biblijski onimi u hrvatskome jeziku“, Folia onomastica croatica, Zagreb, br. 23, str. 185-208.

- Opašsć, Maja (2013) Biblizmi u hrvatskome jeziku, doktorska disertacija, Filozofski fakultet Sveučilišta u Zagrebu, Zagreb.

- Pervan, Tomislav (2006) „Slava božja na Kristovu licu“, Glasnik mira, Međugorje, god. I, br. 2.

- Peti, Mirko (1999) „O tzv. sadržaju imena“, Folia onomastica croatica, Zagreb, br. 8, str. 97-121.

- Pranjković, Ivo (2006) „Hrvatski jezik i biblijski stil“, Raslojavanje jezika i književnosti: zbornik radova 34. seminara Zagrebačke slavističke škole, BAGIĆ, KREŠIMIR (ur.) FF press, Zagreb, str. 2332.

- Ribarova, Slavomira (2001) „Frazemi s biblijskim osobnim imenima u češkom i hrvatskom jeziku“, Riječ, časopis za slavensku filologiju, god. VII, br. 1, str. 71-77.

- TurK, Marija (1994) „Naznake o podrijetlu frazema”, Flumensia, Rijeka, br. 1-2.

- VAJS, NADA - ZeČEviĆ, Vesna (1994) „Frazeologija u Rječniku hrvatskoga kajkavskoga književnog jezika“, Filologija, Zagreb, br. 22-23, str. 175-185.

- Vidović Bolt, Ivana (2011) Životinjski svijet u hrvatskoj i poljskoj frazeologiji I., Hrvatska sveučilišna naklada, Zagreb 
Review article

Received April 30, 2019.

Senka Marinčić - Magdalena Ramljak - Darija Glibić

University of Mostar, Faculty of Humanities and Social Sciences

\section{PHRASEMES WITH BIBLICAL PROPER NAMES IN GERMAN AND CROATIAN DICTIONARIES}

\section{Abstract}

The paper analyzes phrasemes with Biblical proper names as a component in German as the source language and Croatian as the target language, relying on the equivalence typology in the framework of contrastive phraseology. The aim of the paper is to analyze Biblical origin of phrasemes, explain their background, motivation and meaning as well as to determine the level of their equivalence. For collecting materials we used monolingual and bilingual phraseological dictionaries and monolingual and bilingual general dictionaries. According to the expectations, the most dominant are the phrasemes with Biblical proper name as the component, which show partial or full correspondence of the lexeme and morfosyntactic structure with equivalence of phraseological meaning. The unexpected result is a big group of phrasemes that are not recorded in Croatian materials, although literal translations can be found very often in Biblical texts.

Keywords: phraseme; Biblical proper name; equivalence; German; Croatian 


\section{PHRASEOLOGISMEN MIT BIBLISCHEN EIGENNAMEN IN DEUTSCHEN UND KROATISCHEN WÖRTERBÜCHERN}

\section{Zusammenfassung}

In der vorliegenden Arbeit werden biblische Phraseologismen, in deren Verbindung Eigennamen als Komponente auffindbar sind, im Deutschen als Ausgangssprache und im Kroatischen als Zielsprache analysiert, wobei auf die Äquivalenztypologie im Rahmen der kontrastiven Phraseologieforschung gestützt wird. Ziel der Arbeit ist die Untersuchung der biblischen Phrasemherkunft, die Erläuterung deren Bild(haftigkeit), Motivation und Bedeutung sowie die Feststellung ihrer interlingualen Äquivalenzbeziehungen. Bei der Zusammenstellung des Korpus standen uns einsprachige und zweisprachige phraseologische Wörterbücher zur Verfügung sowie allgemeine einsprachige und zweisprachige Wörterbücher. Meist vertreten sind erwartungsgemä $\beta$ Phraseologismen mit partieller und voller Äquivalenz, die lexikalische und morphosyntaktische Strukturen mit gleicher phraseologischer Bedeutung aufweisen. Eine unerwartet große Gruppe bilden Phraseologismen, die in den untersuchten Wörterbüchern der kroatischen Sprache nicht vorhanden sind, obwohl sie in biblischen Texten oft als eine wörtliche Übersetzung aufzufinden sind.

Schlüsselwörter: Phrasem; biblische Eigennamen; Äquivalenz; Deutsch; Kroatisch 